\title{
Beaver creates early successional hotspots for water beetles
}

\author{
Petri Nummi ${ }^{1}$ (D) . Wenfei Liao ${ }^{2}$ (D) . Juliette van der Schoor ${ }^{3,4} \cdot$ John Loehr $^{4}$ (D)
}

Received: 16 September 2020 / Revised: 16 May 2021 / Accepted: 24 May 2021 /

Published online: 4 June 2021

(c) The Author(s) 2021

\begin{abstract}
Beavers (Castor spp.) are ecosystem engineers that induce local disturbance and ecological succession, which turns terrestrial into aquatic ecosystems and creates habitat heterogeneity in a landscape. Beavers have been proposed as a tool for biodiversity conservation and ecosystem restoration. So far, most research has compared biodiversity in beaver wetlands and non-beaver wetlands, but few studies have explored how beaver-created succession affects specific taxa. In this study, we investigated how water beetles responded to different successional stages of wetlands in a beaver-disturbed landscape at Evo in southern Finland. We sampled water beetles with 1-L activity traps in 20 ponds, including: 5 new beaver ponds, 5 old beaver ponds, 5 former beaver ponds, and 5 never engineered ponds. We found that beaver wetlands had higher species richness and abundance than non-beaver wetlands, and that new beaver wetlands could support higher species richness $(321 \%)$ and abundance $(671 \%)$ of water beetles compared to old beaver wetlands. We think that higher water beetle diversity in new beaver ponds has resulted from habitat amelioration (available lentic water, shallow shores, aquatic vegetation, and low fish abundance) and food source enhancement (an increase of both dead and live prey) created by beaver dams and floods. We conclude that using beavers as a tool, or imitating their way of flooding, can be beneficial in wetland restoration if beaver population densities are monitored to ensure the availability of newly colonizable sites.
\end{abstract}

Keywords Aquatic insect · Biodiversity · Conservation · Dytiscidae · Facilitation · Landscape heterogeneity

Communicated by Jens Wolfgang Dauber.

Wenfei Liao

wenfei.liao@ helsinki.fi

1 Department of Forest Sciences, University of Helsinki, P.O. Box 27, 00014 Helsinki, Finland

2 Faculty of Biological and Environmental Sciences, University of Helsinki, P.O. Box 65, 00014 Helsinki, Finland

3 Department of Applied Biology, HAS University of Applied Sciences, Onderwijsboulevard 221, 5223 DE 's-Hertogenbosch, The Netherlands

4 Lammi Biological Station, University of Helsinki, Pääjärventie 320, 16900 Lammi, Finland 


\section{Introduction}

Habitat heterogeneity is an essential factor in creating biodiversity at the landscape level (Turner et al. 2001; Hammill et al. 2018). Landscapes often consist of an array of patches with different qualities, such as different levels of nutrients and moisture (Pickett and Rogers 1997; Barnes et al. 2016). In a landscape with a high degree of environmental heterogeneity, landscape level diversity is high even if the patch level diversities " $\alpha$ " do not differ. Therefore, heterogeneous landscapes have higher turnover " $\beta$ " and landscape level diversity " $\gamma$ " than homogeneous landscapes. Higher levels of species turnover " $\beta$ " may be associated with increased ecosystem functioning in heterogeneous landscapes, as communities may perform different functions under varying environmental conditions (Thompson and Gonzales 2016). Furthermore, the presence of functionally dominant species can have major impacts on ecosystem function since they can push ecological systems to a different state (Naeem et al. 2012; Hammill et al. 2018). For example, in northern boreal and temperate environments, beavers cause patch disturbance, which consequentially leads to a successional mosaic in a landscape (Remillard et al. 1987; Johnston 2017; Kivinen et al. 2020).

Patch disturbance is an essential process creating patch-level variability and landscapelevel heterogeneity. Disturbances can be produced either through abiotic or biotic means (White 1979; Turner et al. 1997; Nummi and Kuuluvainen 2013). Beavers (Castor spp.) are ecologically powerful organisms causing biotic disturbance. As ecosystem engineers they significantly modify their physical environment by damming and digging (Jones et al. 1994; Romero et al. 2015). In this way, they modulate the availability of resources to other species (Hastings et al. 2007). The effect of disturbance by beaver flooding is extremely strong, as it turns a terrestrial ecosystem into an aquatic one (Johnston 2017). Both North American (Castor canadensis Kühl) and Eurasian beavers (Castor fiber L.) are postulated to have a similar effect on wetland ecosystems (Danilov and Fyodorov 2015). Beavers are found to affect communities of a mixture of species groups, such as plants (Wright et al. 2002), invertebrates (Bush and Wissinger 2016), waterbirds (Nummi and Holopainen 2014), and mammals (Nummi et al. 2011, 2019).

Disturbance and succession are inextricably linked in landscape dynamics (Turner et al. 2001). Disturbed patches in a landscape usually are in different points of a successional gradient (Calvo et al. 2002), and the intermingling of these patches in the landscape forms a spatiotemporally heterogeneous system (Kleyer et al. 2007). A beaver-engineered landscape is heterogeneous with patches in various phases of their succession: some patches are aquatic, while some patches become terrestrial after beaver abandonment (Remillard et al. 1987; Naiman et al. 1988; Kivinen et al. 2020). Understanding successional patterns must include comprehension of variance with respect to disturbance intensity and frequency during the processes (van der Maarel 1993; Turner et al. 2001).

Beavers have recovered both in America and Eurasia after being on the verge of extinction in the early 1900s (Halley et al. 2020; Whitfield et al. 2015). With the recent increase of beaver populations, it is estimated that ca. $25,000 \mathrm{~km}^{2}$ of new aquatic pond habitat and $550,000 \mathrm{~km}$ of riparian interface have been created in boreal and temperate zones (Whitfield et al. 2015). Beavers have been proposed as a tool for biodiversity conservation (Law et al. 2019; Nummi and Holopainen 2020), and several studies have shown that beavercreated succession can affect aquatic invertebrates in a beaver-modified landscape at a general level (Bush et al. 2019; Washko et al. 2020). One of the first studies to focus on a specific taxon of aquatic invertebrates found a difference in water beetle abundance in 
beaver wetlands and non-beaver wetlands (Willby et al. 2018). Yet, little is known about how specific taxa, such as water beetles, respond to beaver-created wetlands at different successional stages (but see Bush and Wissinger 2016).

As many water beetles are active dispersers, they can easily reach and benefit from newly created beaver wetlands with abundant food sources, such as detritivore prey (McDowell and Naiman 1986; Nummi 1989; Bush and Wissinger 2016). With the succession of beaver-created wetlands, the habitat characteristics undergo both abiotic and biotic changes, such as increasing abundance of fishes as succession progresses. Consequently, mature beaver ponds may lose their initially attractive characteristics and become suboptimal to water beetles. If beavers are used as a conservation tool to enhance biodiversity, including aquatic insect diversity, it is crucial to understand how different insect groups, such as water beetles, respond to succession in beaver-created wetlands. In this study, we focus on water beetles, which have been suggested as a surrogate taxon for wetland biodiversity studies, since they are diverse, easily sampled, ecologically well understood and occurring across a wide range of wetland types (Bilton et al. 2006).

The aim of this research was to investigate how water beetles responded to different successional stages of beaver disturbed habitats. With previous research showing that the abundance of large gaped invertivorous fish grows throughout succession (Snodgrass and Meffe 1998; Bush and Wissinger 2016), we hypothesize that (1) recently flooded areas have the highest abundance and species richness of water beetles; (2) the abundance and species richness of water beetles will decrease when beaver wetlands become mature, and (3) an array of successional stages will contribute to the species turnover " $\beta$ " in the landscape.

\section{Materials and methods}

\section{Study sites}

Our study site was located at Evo $\left(61^{\circ} 12^{\prime} \mathrm{N}, 25^{\circ} 07^{\prime} \mathrm{E}\right)$ in southern Finland (Nummi and Pöysä 1993; Arvola et al. 2010). Lakes of this area are oligotrophic, and relatively small (0.1-49.5 ha). The study area is mostly covered by boreal forest with limited influences by agriculture and human settlement. The lakeshores of the study area in general are steep, the sparse emergent vegetation consisting mainly of sedges (Carex spp.) and common reed (Phragmites australis). Narrow belts of yellow water lilies (Nuphar lutea) and water lilies (Nymphaea candida) usually line emergent vegetation; the amount of submerged vegetation is limited.

North American beavers (Castor canadensis) inhabit the study area (Parker et al. 2012) and are the main contributors to the environmental variability in the landscape (Suhonen et al. 2011). At Evo, beavers primarily create flowages by damming existing ponds but they sometimes also dam creeks (Nummi and Hahtola 2008; Hyvönen and Nummi 2008). All these habitats contain fish. Within the Evo landscape, beavers move from one lake to another every three years on average, resulting in abandoning old sites and creating new beaver habitat patches (Hyvönen and Nummi 2008; Kivinen et al. 2020). Beaver-created wetlands have significantly shallower shores than non-beaver ponds and contain inundated herbaceous vegetation and bushes (Nummi and Hahtola 2008). To study how water beetles responded to beaver-created succession, we selected four types of ponds having five replicates in each category: (1) new beaver ponds are newly formed ponds between 2 and 4 years old that have raised water level through damming; (2) old beaver ponds are those 
that beavers may or may not be currently present in, but the beaver constructed dam still functions and maintains a raised water level (7-33 years old); (3) former beaver ponds are those with no current beaver presence and which have previously had raised water level due to a beaver constructed dam, but the dam has been breached and the water level has dropped; and (4) never engineered ponds are those which have not encountered raised water level through beaver damming during the last 50 years (Kivinen et al. 2020).

\section{Sampling methods}

We employed activity traps without bait to sample water beetles. The traps consisted of $1 \mathrm{~L}$ glass jars with a funnel of $10 \mathrm{~cm}$ at the large end and $2.3 \mathrm{~cm}$ at the narrow end (Elmberg et al. 1992). At each location, we placed 10 traps approximately $1 \mathrm{~m}$ from the shoreline where the water was at least $30 \mathrm{~cm}$ of depth. The traps were placed horizontally on the bottom and attached to the surrounding vegetation to keep them in place. We measured the depth of each trap $(\mathrm{cm})$ and estimated the percentage of vegetation of the sampling locations, then we averaged these parameters for each pond. After $48 \mathrm{~h}$, traps were emptied by sieving the content using a sieve with $1 \mathrm{~mm}$ mesh. The water beetles were preserved in $70 \%$ ethanol until identification, while other invertebrates were released back to water. Adult beetles were identified to the species level (Holmen 1987; Nilsson and Holmen 1995), and the nomenclature of water beetle species follows Nilsson (2011) and Nilsson and Hájek (2018). We measured water pH with Thermo Electric® Orion 3 star pH benchtop in each pond. The fieldwork took place from 16 May until 6 June 2019.

The activity traps caught few beetles in abandoned beaver ponds and never beaver engineered ponds, which may affect the comparison of beetle assemblages between beaver ponds and non-beaver ponds. In some research (e.g. Law et al. 2019), D-shaped handnets have been utilized to sample water beetles, which has yielded more beetle individuals in non-beaver ponds than the activity traps in our study. Sampling with handnets can be biased by how experienced a collector is, while activity traps can miss sedentary species. In carabid studies, pitfall traps can easily standardize sampling effort but record fewer redlist species compared with handnet sampling by experienced collectors, while greenhand collectors record fewer species than pitfall traps (Knapp et al. 2020). In water beetle studies, we also encounter a similar dilemma in that activity traps can standardize sampling effort but miss some sedentary species.

\section{Statistical analysis}

We applied generalised linear mixed models (GLMM) to examine how water beetles responded to beaver disturbance (package "glmmTMB" in $\mathrm{R}$ software version 3.6.1; Brooks et al. 2017; R Core Team 2018). The species richness and abundances that follow Poisson distribution were entered as response variables, and the stage of ponds (four categories) was entered as a fixed explanatory variable, detailed description in Appendix 1. As the traps were nested in ponds, we included ponds as random effects in our GLMM models. Furthermore, we applied non-metric multidimensional scaling (NMDS) with Bray-Curtis dissimilarity to compare the water beetle assemblages in new beaver ponds and old beaver ponds. We did not include the former beaver ponds and never beaver engineered ponds in NMDS analysis due to the very sparse data of water beetle assemblages. We analysed how pond types, water $\mathrm{pH}$, water depth, and vegetation cover were associated with water beetle assemblages (function "envfit" in package "vegan" in R; Oksanen et al. 

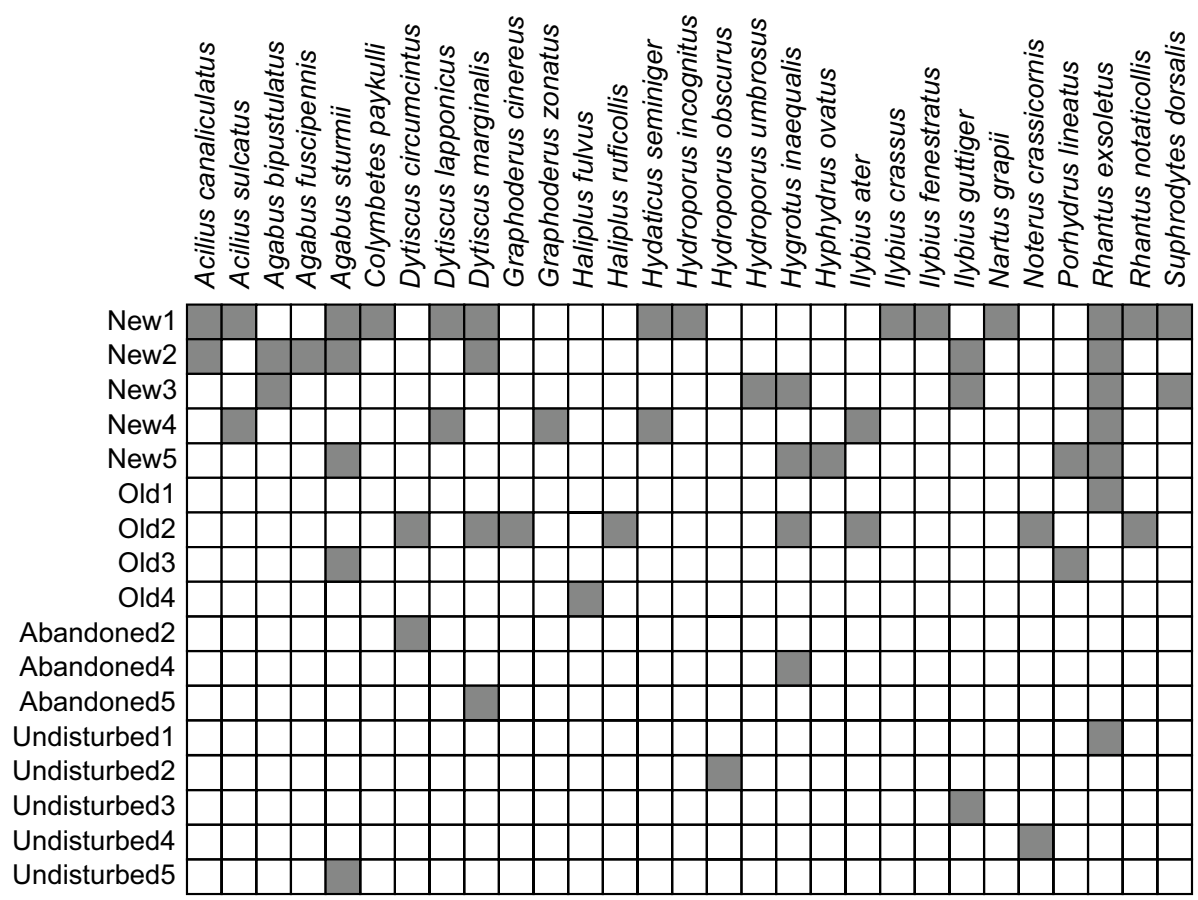

Fig. 1 Raw data of water beetle species richness and abundance per trap in each pond type. The box represents the data from Quantile 1 to Quantile 3; the black bar in each box represents the median; the open circles represent outliers. The different letters in the figure represent significant difference. For example, new beaver ponds, labelled with 'a', have significantly more species than old beaver ponds, labelled with ' $b$ '

2018). We calculated Whittaker indices with function "betadiver" and applied functions "adonis" and "betadisper" to study beta diversity and differences in group homogeneities (Oksanen et al. 2018). We applied functions "anova" and "permutest" to conduct analysis of variance of beta diversity and permutation test for homogeneity of multivariate dispersions (Oksanen et al 2018). We only compared beta diversity in new beaver ponds and old beaver ponds, while we omitted the former beaver ponds and never beaver engineered ponds due to sparse beetle data.

\section{Results}

In total, we obtained 192 specimens from 29 water beetle species of the families Dytiscidae (26 species), Haliplidae (2 species), and Noteridae (1 species; Fig. 1). Of these, 14 species were only found in new beaver ponds (Fig. 1), three in old beaver ponds, and Hydroporus obscurus only in a never beaver engineered pond. In our study with activity traps, nonbeaver ponds never had more than one water beetle species, while new ponds had up to 14 and old beaver ponds up to eight species. One species, Rhantus exsoletus, was found in all new beaver ponds.

Our GLMM results showed that new beaver ponds had significantly higher water beetle species richness and abundance than old beaver ponds and non-beaver ponds (richness: 
Table 1 Species richness and abundance of water beetles per trap in four types of ponds

\begin{tabular}{llllll}
\hline Pond types & $\begin{array}{l}\text { Water } \\
\text { beetle } \\
\text { occurrence }\end{array}$ & $\begin{array}{l}\text { Total } \\
\text { species } \\
\text { richness }\end{array}$ & Total abundance & $\begin{array}{l}\text { Species rich- } \\
\text { ness per trap } \\
\text { (mean } \pm \text { SD) }\end{array}$ & $\begin{array}{l}\text { Abundance per } \\
\text { trap (mean } \pm \text { SD) }\end{array}$ \\
\hline New beaver ponds & $36 / 50$ & 23 & 162 & $1.60 \pm 1.59 \mathrm{a}$ & $3.24 \pm 5.18 \mathrm{~A}$ \\
Old beaver ponds & $13 / 50$ & 12 & 22 & $0.38 \pm 0.78 \mathrm{~b}$ & $0.42 \pm 0.91 \mathrm{~B}$ \\
$\begin{array}{l}\text { Former beaver ponds } \\
\begin{array}{l}\text { Never beaver engi- } \\
\text { neered }\end{array}\end{array}$ & $3 / 50$ & 3 & 3 & $0.06 \pm 0.24 \mathrm{c}$ & $0.06 \pm 0.24 \mathrm{C}$ \\
\hline
\end{tabular}

We sampled 5 ponds under each pond type and set 10 traps in each pond, i.e. 50 traps under each pond type. The different letters behind the mean values represent statistic significance between two categories; the same letter represents no significance between two categories

*SD means standard deviation
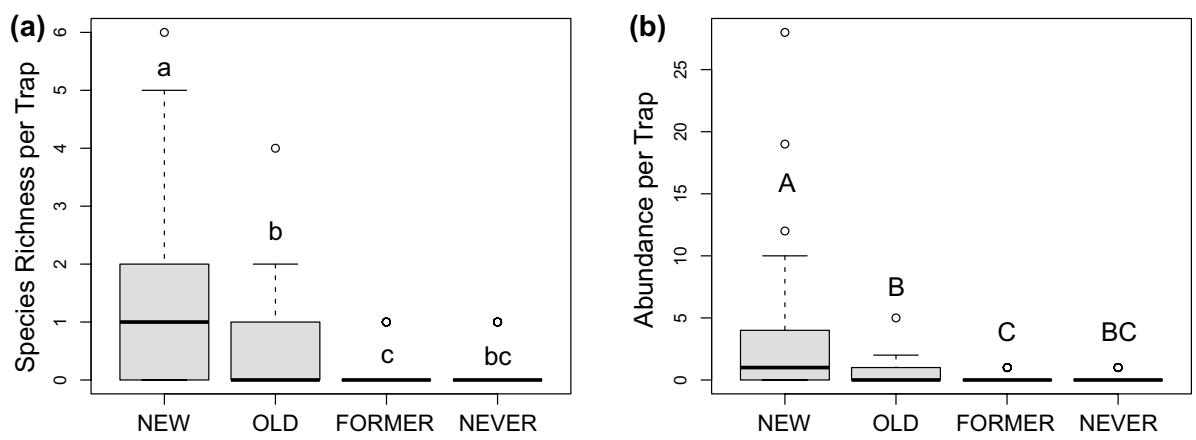

Fig. 2 Water beetle species presence in new and old beaver ponds. A dark square indicates presence. Note that only ponds with beetles shown

$1.60 \pm 1.59$ and $0.38 \pm 0.78$, p-value $<0.001$; and abundance: $3.24 \pm 5.18$ (individuals per trap) and $0.42 \pm 0.91, \mathrm{p}$-value $<0.001$; for new and old ponds, respectively; Table 1 ; Fig. 2). Species richness (Fig. 2a) and abundance (Fig. 2b) of water beetles were $321 \%$ and $671 \%$ higher, respectively, in new beaver ponds compared to old beaver ponds. Species richness and abundance of water beetles were $533 \%(\mathrm{p}$-value $=0.017)$ and $600 \%$ higher $(\mathrm{p}$-value $=0.030)$, respectively, in old beaver ponds compared to former beaver ponds (Table 1). There was no difference in water beetle species richness $(p$-value $=0.518$ ) and abundance $(\mathrm{p}$-value $=0.533$ ) between former beaver ponds and never beaver engineered ponds (Fig. 2).

The NMDS results showed no significant difference in water beetle assemblages between new and old beaver ponds (p-value $=0.844$, Fig. 3a). Still, many species (e.g. Acilius spp., Dytiscus lapponicus) were only recorded in new beaver ponds, and some (e.g. Haliplus spp.) only in old ones (Fig. 1). Water $\mathrm{pH}(\mathrm{p}$-value $=0.139)$, water depth $(p$-value $=0.610)$, and vegetation cover $(p$-value $=0.245)$ had no significant effects on beetle assemblages. The permutational multivariate analysis of variance showed that there was no pond type effect regarding water beetle beta diversity $\left(R^{2}=0.12, F\right.$-value $=0.995$, $\mathrm{p}$-value $=0.542$ ). We found that new beaver ponds (average distance to median $=0.454$ ) had lower variances than old beaver ponds (average distance to median $=0.612$ ), and the 

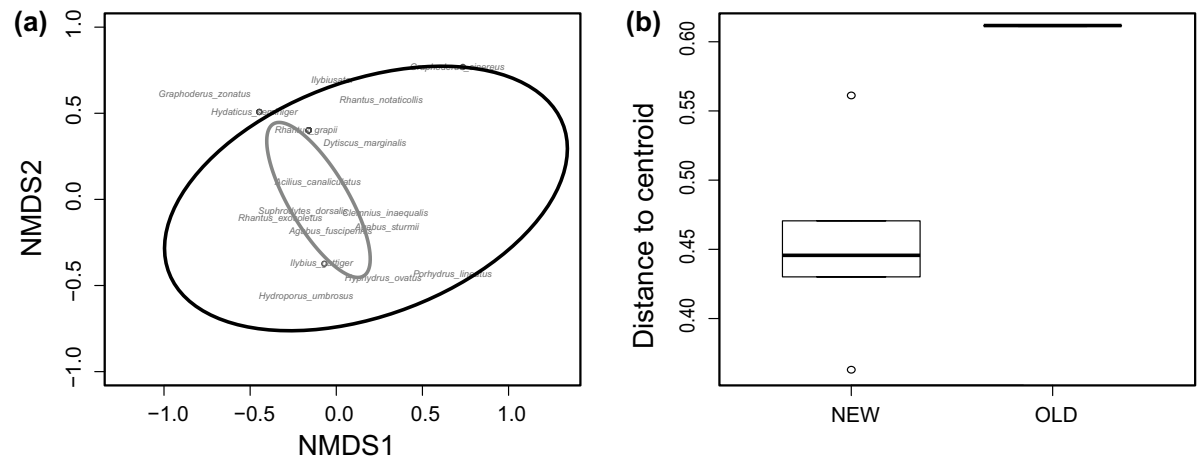

Fig. 3 a NMDS plot of the water beetle assemblages in new beaver ponds (large dark grey circle) and old beaver ponds (small light grey circle). The circles represent $95 \%$ confidence interval of the two pond types. b New beaver ponds have smaller variance in beta diversity than old beaver ponds

permutation test showed a significant difference in dispersion between new and old beaver ponds $(\mathrm{F}$-value $=18.967$, p-value $=0.001$, Fig. 3b).

\section{Discussion}

In our study, we investigated how water beetles responded to different successional stages of beaver ponds. Our results show that the beetles in new beaver ponds were significantly more abundant and species-rich than in other types of wetlands. Water beetle richness decreased when beaver ponds became mature, but they retained high diversity compared to non-beaver ponds. Our results provide support for the role of beavers as ecosystem engineers promoting biodiversity, as beaver wetlands, especially newly created ones, supported more diverse assemblages of water beetles than non-beaver wetlands. We will discuss how the beaver alters habitats and the succession of beaver-created wetlands in the following sections.

\section{Beaver creates suitable habitats}

Our results reveal that beaver ponds support water beetle assemblages of higher diversity than non-beaver ponds, suggesting that beaver dams create habitats suitable for water beetles. Habitat suitability of beaver ponds can be manifested both in the form of habitat structural amelioration and resource enhancement (Table 2; sensu Bruno et al. 2003; Nummi and Hahtola 2008). Intact beaver dams slow down the hydrologic fluxes (Schlosser and Kallemeyn 2000), resulting in habitats with lentic water favoured by most water beetle species (Holmen 1987; Nilsson and Holmen 1995). Beaver construction also creates an inundated area behind the dam. The flooded areas often characterize beneficial habitat features, such as shallow water zones with emergent vegetation (Nummi and Hahtola 2008; Johnston 2017) and an increase in plant and woody debris, which are favoured by water beetles (Nilsson et al. 1994; Willby et al. 2018; Liao et al. 2020). These physical pond characteristics are often associated with biotic changes in beaver ponds. Beaver ponds can also have high within-patch heterogeneity with the 


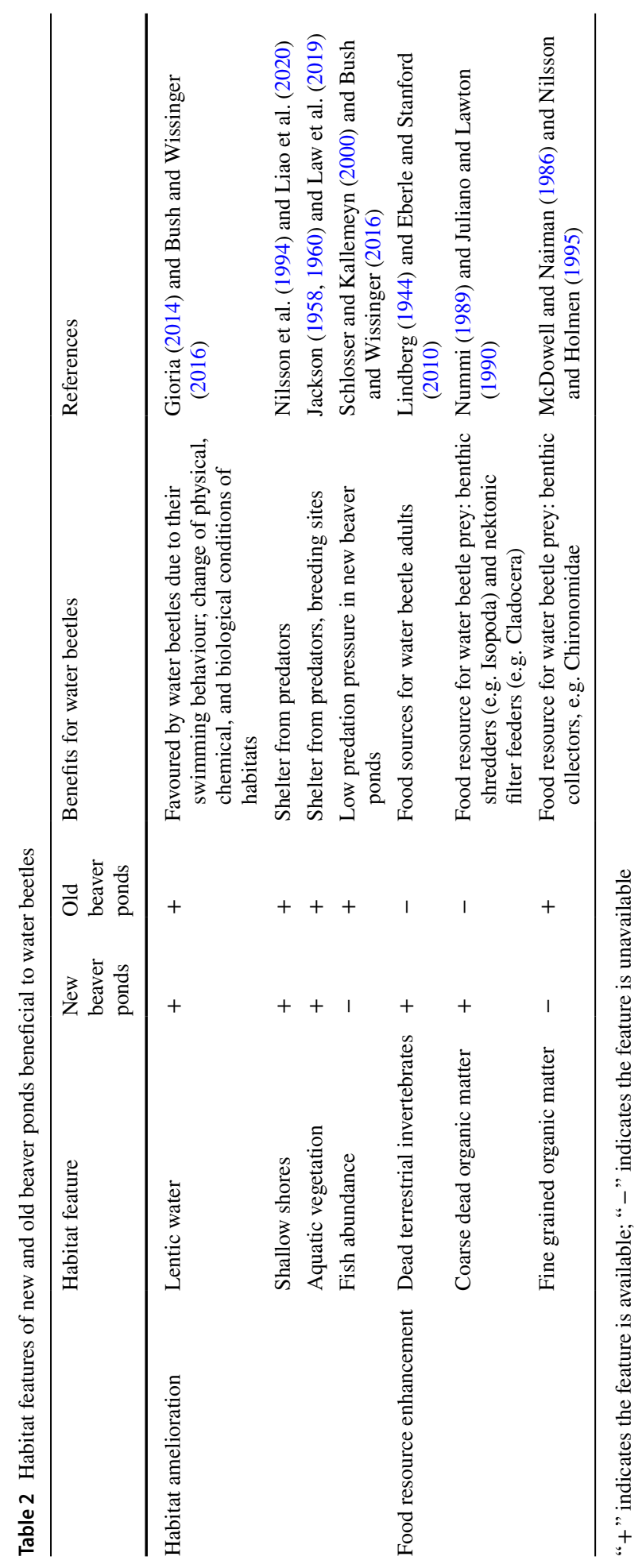


sub-habitats including the relatively deep water behind the dam and in the former creek channel, inundated shrubs-swamps, shallow marshes of emergent vegetation, and vernal wet meadows (Nummi 1989; Wissinger and Gallagher 1999; Bush and Wissinger 2016; Johnston 2017).

Resource enhancement caused by pond physical characteristics occurs in beaver ponds in a way that can benefit water beetles (Table 2). In our traps, Ilybius ater, a species preferring habitats with muddy bottoms rich in detritus harboring numerous prey (Verberk et al. 2001; Frelik and Pakulnicka 2015), was found in both new and old beaver ponds but not in non-beaver ponds. In previous research, Law et al. (2019) found that Ilybius ater was highly associated with their beaver ponds. In beaver ponds, floods usually lead to abundant organic matter accumulating in pond bottoms (Naiman et al. 1986; Johnston 2017; Nummi et al. 2018). This organic matter accumulation results in an increase in the abundance of Chironomidae larvae as well as other detritivorous invertebrates, such as the isopod Asellus sp. (Hodkinson 1975; McDowell and Naiman 1986; Nummi 1989; Law et al. 2016; Bush and Wissinger 2016). Furthermore, beaver-created floods can also lead to increasing availability of terrestrial invertebrates (see Swanson et al. 1985; Eberle and Stanford 2010), which is an additional food resource for adult dytiscids, the most abundant water beetles in our traps (Nilsson and Holmen 1995). These invertebrates, both live and dead (Lindberg 1944; Juliano and Lawton 1990), are a food resource to water beetles which as early colonisers can benefit from resource enhancement at the early successional stage of beaver ponds.

Water beetles can take advantage of these beneficial changes of habitat features via various means of dispersal. In our study, good flier species, such as Acilius canaliculatus and Rhantus exsoletus, were early colonizers and frequently occurred in new beaver ponds (Fig. 2). In North America, Larson et al. (2000) discovered that Acilius, a genus of good fliers, was especially associated with beaver ponds. These early colonisers have the advantage to colonise newly available suitable habitats. In our study, Graphoderus zonatus, a species known to be poor fliers (Eriksson 1972; Lundkvist et al. 2002), also had a very frequent occurrence in one of the new beaver ponds. We think this species could have dispersed from nearby wetlands through aquatic corridors created by beaver floods (Wissinger and Gallagher 1999; Hood and Larson 2015; Bush and Wissinger 2016), as shown for the area by Kivinen et al. (2020). Availability of multiple dispersal pathways, therefore, results in the increase of water beetle species richness in beaver ponds compared to that in nonbeaver ponds.

\section{The succession of beaver-created wetlands affects water beetle assemblages}

In our study, we found that new beaver ponds had higher numbers of water beetles and more diverse assemblages than other wetland types including old beaver ponds. Our result differs from the findings of Bush et al. (2019, see also Bush and Wissinger, 2016) that showed taxa richness of invertebrates being the highest in abandoned (homologous to the category 'former' in our analysis) beaver ponds. Bush et al. (2019) investigated a broad range of macroinvertebrate families that were identified to the family level, while our study focused specifically on water beetles identified to the species level. Therefore, the differing results are likely due to the macroinvertebrate taxonomical level of identification and the ecology of different taxa. Furthermore, it should be noted that the activity traps we were using are especially suitable for capturing mobile water beetles. Sedentary species may, 
thus, be underrepresented in our sampling. When generally studying the effect of pond age on invertebrates, Fairchild et al. (2000) found predatory dytiscids to be especially dwellers of ponds of less than 10 years of age. It is to be noted, though, that according to the variance in the beta diversity, the old beaver ponds of our study were more dissimilar to each other than the new ones.

The first year(s) of beaver impoundments are characterized by abundance of inundated, dying plants providing suitable structure for many aquatic invertebrates (Table 2). In an experiment imitating beaver flooding, Nummi (1989) showed that the group of detritivores especially increasing during the first flood summer are cladocerans. They are important prey for some dytiscids, such as Hydroporus (Nilsson and Holmen 1995) found in some of our new beaver flowages. During the second year of flooding, benthic detritivores, especially the shredder Asellus sp. as well as chironomids, increased; they are preyed upon e.g. by Hyphydrus (Juliano and Lawton 1990). The role of shredders in the invertebrate community can remain high for some years if there are trees in the flowage (especially Salix sp.) which continue to produce leaf litter for detritivores eating coarse matter (Nummi 1989).

From the perspective of invertebrates, an important characteristic of the early stage beaver ponds is the reduced presence of invertivorous fish (Bush and Wissinger 2016). In the short term after damming, the populations of invertivorous fishes are small and recolonization by fish is delayed by the barrier effect of beaver dams (Snodgrass and Meffe 1998). This has the effect of diluting the fish predation pressure on beetles as many water beetles are known to be sensitive to the presence of predatory fish (Nummi et al. 2012; Liao et al. 2020). In our results, the assemblage difference of water beetles found in the early and later successional stages of beaver ponds indicates that some water beetles species indeed could have benefitted from the possible time lag in fish colonization of beaver flowages, partly delayed by the barrier effect of beaver dams.

In later stages of succession, the water beetle species composition seems to partially become a subset of the species pool of the new beaver ponds (Fig. 1), which we think resulted from the higher predation pressure in old beaver ponds. According to North-American studies, large gaped predatory fish replace small fish as beaver ponds become mature, (Snodgrass and Meffe 1998; Bush and Wissinger 2016), and fish abundance reaches its peak in mature beaver ponds (Schlosser and Kallemeyn 2000). Still, these old beaver ponds provide habitats to species, such as the Haliplus spp. (Fig. 1); they are not very active dispersers since they do not often fly, and they are not very vulnerable to fish because of their habit of crawling among vegetation (Yee and Kehl 2015). As noted above, the water beetles of the old beaver ponds occurred in a more uneven way than in the new ones. The presence of the species in the old beaver ponds, which were not found in the new ones (three in all), adds to the species turnover " $\beta$ " in the landscape and reveals the value of also the old beaver ponds in biodiversity conservation at the landscape level.

The species composition change we found in water beetles is likely also partly due to changes in overall productivity of the beaver pond. At the very early stage, water beetles may utilize the abundance of dead terrestrial animal matter (Margolis et al. 2001). As succession progresses water beetles may switch to feeding primarily on detritivores which colonize the pond and benefit from the inundated plant matter (McDowell and Naiman 1986; Nummi 1989). As the beaver pond progresses to later successional stages, detritivore productivity decreases as the effect of the pulse of the organic matter washed from the flooded shores decreases. It has been found to decrease after some years of flooding (Vehkaoja et al. 2015; Nummi et al. 2018) along with the biomass of the former terrestrial vegetation (Nummi 1989). 
Water beetles and other aquatic invertebrates that benefit from newly created beaver wetlands (Nummi 1989; McDowell and Naiman 1986; Bush and Wissinger 2016) appear to attract biodiversity at higher trophic levels. Waterbirds, such as common teal Anas crecca and green sandpiper Tringa ochropus (Nummi and Pöysä 1993; Nummi and Holopainen 2014), are known to benefit from the availability of invertebrates as food in new beaver wetlands. The available aquatic invertebrates in beaver wetlands also facilitate the abundance of mammals, such as bats, via the food web (Nummi et al. 2011). When beaver wetlands become mature, fishes colonize the flooded areas and strongly compete for food with the birds (Schlosser and Kallemayn 2000; Nummi et al. 2012).

Apart from beaver created floods, there are also other temporarily flooded areas in the same study area, boreal vernal pools. Vernal pools harbour even greater abundance and diversity of water beetles than beaver ponds do (Liao and Nummi, pers. obs.) but are even more variable habitats. Vernal pools are very susceptible to drying out early during summers with low amounts of precipitation. Synchronized fluctuations in environmental conditions can reduce the likelihood of insect metapopulations persisting, as could happen from the effect of an extensive drought as an example. The addition of more permanent habitats to a system, such as new beaver ponds, could sometimes enable metapopulation persistence even in cases in which the metapopulation would otherwise go extinct (Frouz and Kindlmann 2015). In our landscape setting, new beaver ponds can act as the "permanent" habitats of the source-sink model. Modifying from Wissinger and Gallagher (1999), we could state that the loss of productive semi-permanent beaver ponds from the wetland complex of the landscape could reduce the pool of cyclic colonizers that seasonally invade temporary habitats. Thus also reducing diversity in those temporary vernal pools. Future studies are needed to investigate the function of and interaction of beaver ponds and vernal pools in water beetle metapopulations.

\section{Conclusions}

The return of beavers is very beneficial from the point of view of many kinds of wetland organisms, such as the water beetles we studied. Within a region, beavers create a spatiotemporal mosaic of patches, which considerably increases landscape heterogeneity. When there are patches in different successional stages in the landscape, suitable habitats are available to different taxa, resulting in different communities in each patch type. Using beavers as a tool or imitating their way of flooding would be beneficial in wetland restoration. Yet, from a biodiversity point of view, beaver population densities should be monitored, because high beaver density can lead to aging of the beaver ponds due to the low availability of newly colonizable sites (Nummi and Kuuluvainen 2013). Our study highlights the benefits of having new beaver patches to support biodiversity in a landscape.

\section{Appendix}

The GLMM Poisson model for the dytiscid species richness data is described below:

$$
Y_{i j} \sim \operatorname{Poisson}\left(\mu_{i j}\right)
$$




$$
\begin{gathered}
\mathrm{E}\left(Y_{i j}\right) \sim \mu_{i j} \\
\log \left(\mu_{i j}\right)=\alpha+\beta_{1} \times \text { New_Beaver_Ponds } s_{i}+\beta_{2} \times \text { Old_Beaver_Ponds } s_{i} \\
+\beta_{3} \times{\text { Former_Beaver_Pond } s_{i}+\beta_{4} \times \text { Never_Beaver_Engineered }}_{i}+\tau_{i}+\varepsilon_{i j}
\end{gathered}
$$

where the $j$ th species richness observation in pond $i, Y_{i j}$, is Poisson distributed with mean $\mu_{i j}$. The covariates are the four categories of pond types, i.e. New Beaver Ponds, Old Beaver Ponds, Former Beaver Ponds, and Never Beaver Engineered Ponds. The term $\alpha$ is the intercept and the terms $\beta_{1}, \beta_{2}, \beta_{3}$ and $\beta_{4}$ are the parameters of the four categories. In the statistical results that we obtained in the R software, one of the four categories 'disappears' and goes to the reference level, i.e. the intercept. It is possible to set a different category as the reference level to allow the comparison between the categories. The term $\tau_{i}$ is pond as a random effect, as trap observations are nested in ponds. We assume the random effect is normally distributed with mean 0 and variance $\sigma_{\tau}{ }^{2}$. The term $\varepsilon_{i j}$ is the unexplained information that is assumed to be normally distributed with expectation 0 and variance $\sigma_{\varepsilon}^{2}$.

The observations of dytiscid abundance have the same model description, except that $Y_{i j}$ means the $j$ th abundance observation in pond $i$.

Acknowledgements We want to thank Christoph Kubin for helping in the field and Anders Nilsson for finding important old dytiscid literature. We also would like to thank Aleksi Lehikoinen and Janne Soininen for commenting on an earlier version of the manuscript. We would like thank the two anonymous reviewers for their constructive comments.

Author contributions PN and WL designed the study; JL arranged the fieldwork, and JS conducted fieldwork; JS identified water beetles with the assistance of WL; WL conducted data analysis; PN led the writing; WL, JS, JL revised the intellectual contents critically.

Funding Open access funding provided by University of Helsinki including Helsinki University Central Hospital.

Data Availability We will make data available under request.

Open Access This article is licensed under a Creative Commons Attribution 4.0 International License, which permits use, sharing, adaptation, distribution and reproduction in any medium or format, as long as you give appropriate credit to the original author(s) and the source, provide a link to the Creative Commons licence, and indicate if changes were made. The images or other third party material in this article are included in the article's Creative Commons licence, unless indicated otherwise in a credit line to the material. If material is not included in the article's Creative Commons licence and your intended use is not permitted by statutory regulation or exceeds the permitted use, you will need to obtain permission directly from the copyright holder. To view a copy of this licence, visit http://creativecommons.org/licenses/by/4.0/.

\section{References}

Arvola L, Rask M, Ruuhijärvi J, Tulonen T, Vuorenmaa J, Ruoho-Airola T, Tulonen J (2010) Long-term patterns in $\mathrm{pH}$ and colour in small acidic boreal lakes of varying hydrological and landscape settings. Biogeochemistry 101(1-3):269-279. https://doi.org/10.1007/s10533-010-9473-y

Barnes AD, Weigelt P, Jochum M, Ott D, Hodapp D, Haneda NF, Brose U (2016) Species richness and biomass explain spatial turnover in ecosystem functioning across tropical and temperate ecosystems. Philos Trans R Soc B 371(1694):20150279. https://doi.org/10.1098/rstb.2015.0279

Bilton DT, Mcabendroth L, Bedford A, Ramsay PM (2006) How wide to cast the net? Cross-taxon congruence of species richness, community similarity and indicator taxa in ponds. Freshw Biol 51(3):578-590 
Brooks ME, Kristensen K, van Benthem KJ, Magnusson A, Berg CW, Nielsen A, Bolker BM (2017) glmmTMB balances speed and flexibility among packages for zero-inflated generalized linear mixed modeling. R J 9(2):378-400

Bruno JF, Stachowicz JJ, Bertness MD (2003) Inclusion of facilitation into ecological theory. Trends Ecol Evol 18(3):119-125. https://doi.org/10.1016/S0169-5347(02)00045-9

Bush BM, Wissinger SA (2016) Invertebrates in beaver-created wetlands and ponds. In: Batzer D, Boix D (eds) Invertebrates in freshwater wetlands. Springer, Cham, pp 411-449

Bush BM, Stenert C, Maltchik L, Batzer DP (2019) Beaver-created successional gradients increase $\beta$-diversity of invertebrates by turnover in stream-wetland complexes. Freshw Biol 64(7):1265-1274. https://doi.org/10.1111/fwb.13302

Calvo L, Tárrega R, de Luis E (2002) Secondary succession after perturbations in a shrubland community. Acta Oecologica 23(6):393-404. https://doi.org/10.1016/S1146-609X(02)01164-5

Danilov PI, Fyodorov FV (2015) Comparative characterization of the building activity of Canadian and European beavers in northern European Russia. Russ J Ecol 46(3):272-278. https://doi.org/10.1134/ S1067413615030029

Eberle LC, Stanford JA (2010) Importance and seasonal availability of terrestrial invertebrates as prey for juvenile salmonids in floodplain spring brooks of the Kol River (Kamchatka, Russian Federation). River Res Appl 26(6):682-694. https://doi.org/10.1002/rra.1270

Elmberg J, Nummi P, Pöysä H, Sjöberg K (1992) Do intruding predators and trap position affect the reliability of catches in activity traps? Hydrobiologia 239(3):187-193. https://doi.org/10.1007/BF00007676

Eriksson U (1972) The invertebrate fauna of the Kilpisjärvi area, Finnish Lapland. 10. Dytiscidae. Acta Soc Fauna Flora Fenn 80:121-160

Fairchild GW, Faulds AM, Matta JF (2000) Beetle assemblages in ponds: effects of habitat and site age. Freshw Biol 44(3):523-534. https://doi.org/10.1046/j.1365-2427.2000.00601.x

Frelik A, Pakulnicka J (2015) Relations between the structure of benthic macro-invertebrates and the composition of adult water beetle diets from the Dytiscidae family. Environ Entomol 44(5):1348-1357. https://doi.org/10.1093/ee/nvv113

Frouz J, Kindlmann P (2015) Source-sink colonization as a possible strategy of insects living in temporary habitats. PLoS ONE 10(6):e0127743. https://doi.org/10.1371/journal.pone.0127743

Gioria M (2014) Habitats. In: Yee D (ed) Ecology, systematics, and the natural history of predaceous diving beetles (Coleoptera: Dytiscidae). Springer, Dordrecht, pp 307-362

Halley DJ, Saveljev AP, Rosell F (2020) Population and distribution of beavers Castor fiber and Castor canadensis in Eurasia. Mamm Rev. https://doi.org/10.1111/mam.12216

Hammill E, Hawkins CP, Greig HS, Kratina P, Shurin JB, Atwood TB (2018) Landscape heterogeneity strengthens the relationship between $\beta$-diversity and ecosystem function. Ecology 99(11):2467-2475. https://doi.org/10.1002/ecy.2492

Hastings A, Byers JE, Crooks JA, Cuddington K, Jones CG, Lambrinos JG, Wilson WG (2007) Ecosystem engineering in space and time. Ecol Lett 10(2):153-164. https://doi.org/10.1111/j.1461-0248.2006. 00997.x

Hodkinson ID (1975) Energy flow and organic matter decomposition in an abandoned beaver pond ecosystem. Oecologia 21(2):131-139. https://doi.org/10.1007/BF00345556

Holmen M (1987) The aquatic Adephaga (Coleoptera) of Fennoscandia and Denmark. Brill, Leiden

Hood GA, Larson DG (2015) Ecological engineering and aquatic connectivity: a new perspective from beaver-modified wetlands. Freshw Biol 60(1):198-208. https://doi.org/10.1111/fwb.12487

Hyvönen T, Nummi P (2008) Habitat dynamics of beaver Castor canadensis at two spatial scales. Wildl Biol 14(3):302-308. https://doi.org/10.2981/0909-6396(2008)14[302:HDOBCC]2.0.CO;2

Jackson DJ (1958) Egg-laying and egg-hatching in Agabus bipustulatus L., with notes on oviposition in three species of Agabus (Coleoptera: Dytiscidae). Trans R Entomol Soc Lond 110(3):53-80

Jackson DJ (1960) Observations on egg-laying in Ilybius fuliginosus Fabricius and I. ater Degeer (Coleoptera: Dytiscidae), with an account of the female genitalia. Trans R Entomol Soc Lond 112(3):37-52

Johnston CA (2017) Beavers: boreal ecosystem engineers. Springer, Cham

Jones CG, Lawton JH, Shachak M (1994) Organisms as ecosystem engineers. In: Samson FB, Fritz LK (eds) Ecosystem management. Springer, New York, pp 130-147

Juliano SA, Lawton JH (1990) Extrinsic vs. intrinsic food shortage and the strength of feeding links: effects of density and food availability on feeding rate of Hyphydrus ovatus. Oecologia 83(4):535-540. https://doi.org/10.1007/BF00317206

Kivinen S, Nummi P, Kumpula T (2020) Beaver-induced spatiotemporal patch dynamics affect landscapelevel environmental heterogeneity. Environ Res Lett 15:094065. https://doi.org/10.1088/1748-9326/ ab9924 
Kleyer M, Biedermann R, Henle K, Obermaier E, Poethke HJ, Poschlod P, Vetterlein D (2007) Mosaic cycles in agricultural landscapes of Northwest Europe. Basic Appl Ecol 8(4):295-309. https://doi.org/ 10.1016/j.baae.2007.02.002

Knapp M, Knappová J, Jakubec P, Vonička P, Moravec P (2020) Incomplete species lists produced by pitfall trapping: how many carabid species and which functional traits are missing? Biol Conserv 245:108545. https://doi.org/10.1016/j.biocon.2020.108545

Larson DJ, Alarie Y, Roughley RE (2000) Predaceous diving beetles (Coleoptera: Dytiscidae) of the Nearctic Region, with emphasis on the fauna of Canada and Alaska. NRC Research Press, Ottawa

Law A, McLean F, Willby NJ (2016) Habitat engineering by beaver benefits aquatic biodiversity and ecosystem processes in agricultural streams. Freshw Biol 61(4):486-499. https://doi.org/10.1111/fwb. 12721

Law A, Levanoni O, Foster G, Ecke F, Willby NJ (2019) Are beavers a solution to the freshwater biodiversity crisis? Divers Distrib 25(11):1763-1772. https://doi.org/10.1111/ddi.12978

Liao W, Venn S, Niemelä J (2020) Environmental determinants of diving beetle assemblages (Coleoptera: Dytiscidae) in an urban landscape. Biodivers Conserv 29:2343-2359. https://doi.org/10.1007/ s10531-020-01977-9

Lindberg H (1944) Okologisch-geographische Untersuchungen zur Insektenfauna der Felsentümpel an den Küsten Finnlands. Soc. pro fauna et flora Fennica

Lorri C, Eberle Jack A, Stanford (2010) Importance and seasonal availability of terrestrial invertebrates as prey for juvenile salmonids in floodplain spring brooks of the Kol River (Kamchatka Russian Federation). River Res Appl 26(6):682-694. https://doi.org/10.1002/rra.1270

Lundkvist E, Landin J, Karlsson F (2002) Dispersing diving beetles (Dytiscidae) in agricultural and urban landscapes in south-eastern Sweden. Annales Zoologici Fennici 39(2):109-123

Margolis BE, Raesly RL, Shumway DL (2001) The effects of beaver-created wetlands on the benthic macroinvertebrate assemblages of two Appalachian streams. Wetlands 21(4):554. https://doi.org/10.1672/ 0277-5212(2001)021[0554:TEOBCW]2.0.CO;2

McDowell DM, Naiman RJ (1986) Structure and function of a benthic invertebrate stream community as influenced by beaver (Castor canadensis). Oecologia 68(4):481-489. https://doi.org/10.1007/BF003 78759

Naeem S, Duffy JE, Zavaleta E (2012) The functions of biological diversity in an age 536 of extinction. Science 336:1401-1406

Naiman RJ, Melillo JM, Hobbie JE (1986) Ecosystem alteation of boreal forest streams by beaver (Castor canadensis). Ecology 67(5):1254-1269. https://doi.org/10.2307/1938681

Naiman RJ, Johnston CA, Kelley JC (1988) Alteration of North American streams by beaver. Bioscience 38(11):753-762. https://doi.org/10.2307/1310784

Nilsson AN (2011) A world catalogue of the family Noteridae, or the burrowing water beetles (Coleoptera, Adephaga). Version 16. VIII

Nilsson AN, Hájek J (2018) A world catalogue of the family Dytiscidae, or the diving beetles (Coleoptera, Adephaga). Version 1. I. 2018

Nilsson AN, Holmen M (1995) The Aquatic Adephaga (Coleoptera) of the Fennoscandia and Denmark II-Dytiscidea, Ii Dytiscidae. Brill, Leiden

Nilsson AN, Elmberg J, Sjoberg K (1994) Abundance and species richness patterns of predaceous diving beetles (Coleoptera, Dytiscidae) in Swedish lakes. J Biogeogr 21:197-206

Nummi P (1989) Simulated effects of the beaver on vegetation, invertebrates and ducks. Ann Zool Fenn 26:43-52

Nummi P, Hahtola A (2008) The beaver as an ecosystem engineer facilitates teal breeding. Ecography 31(4):519-524. https://doi.org/10.1111/j.0906-7590.2008.05477.x

Nummi P, Holopainen S (2014) Whole-community facilitation by beaver: ecosystem engineer increases waterbird diversity. Aquat Conserv 24(5):623-633. https://doi.org/10.1002/aqc.2437

Nummi P, Holopainen S (2020) Restoring wetland biodiversity using research: whole-community facilitation by beaver as framework. Aquat Conserv. https://doi.org/10.1002/aqc.3341

Nummi P, Kuuluvainen T (2013) Forest disturbance by an ecosystem engineer: beaver in boreal landscapes. Boreal Environ Res 18:13-24

Nummi P, Pöysä H (1993) Habitat associations of ducks during different phases of the breeding season. Ecography 16:319-328. https://doi.org/10.1111/j.1600-0587.1993.tb00221.x

Nummi P, Kattainen S, Ulander P, Hahtola A (2011) Bats benefit from beavers: a facilitative link between aquatic and terrestrial food webs. Biodivers Conserv 20(4):851-859. https://doi.org/10. 1007/s10531-010-9986-7 
Nummi P, Väänänen VM, Rask M, Nyberg K, Taskinen K (2012) Competitive effects of fish in structurally simple habitats: perch, invertebrates, and goldeneye in small boreal lakes. Aquat Sci 74(2):343-350. https://doi.org/10.1007/s00027-011-0225-4

Nummi P, Vehkaoja M, Pumpanen J, Ojala A (2018) Beavers affect carbon biogeochemistry: both shortterm and long-term processes are involved. Mamm Rev 48(4):298-311. https://doi.org/10.1111/ mam.12134

Nummi P, Liao W, Huet O, Scarpulla E, Sundell J (2019) The beaver facilitates species richness and abundance of terrestrial and semi-aquatic mammals. Glob Ecol Conserv 20:e00701. https://doi.org/ 10.1016/j.gecco.2019.e00701

Oksanen J, Blanchet FG, Friendly M, Kindt R, Legendre P, McGlinn D, Minchin PR, Wagner H (2018) vegan: Community Ecology Package. R package version 2.5-3. https:/CRAN.R-project.org/packa ge= vegan

Parker H, Nummi P, Hartman G, Rosell F (2012) Invasive North American beaver Castor canadensis in Eurasia: a review of potential consequences and a strategy for eradication. Wildl Biol 18(4):354365. https://doi.org/10.2981/12-007

Pickett ST, Rogers KH (1997) Patch dynamics: the transformation of landscape structure and function. In: Bissonette JA (ed) Wildlife and landscape ecology. Springer, New York, pp 101-127

R Core Team (2018) R: a language and environment for statistical computing. R Foundation for Statistical Computing, Vienna, Austria. https://www.R-project.org/

Remillard MM, Gruendling GK, Bogucki DJ (1987) Disturbance by beaver (Castor canadensi) and increased landscape heterogeneity. In: Turner MG (ed) Landscape heterogeneity and disturbance, vol 64. Springer, New York, pp 103-122

Romero GQ, Gonçalves-Souza T, Vieira C, Koricheva J (2015) Ecosystem engineering effects on species diversity across ecosystems: a meta-analysis. Biol Rev 90(3):877-890. https://doi.org/10.1111/brv. 12138

Schlosser IJ, Kallemeyn LW (2000) Spatial variation in fish assemblages across a beaver-influenced successional landscape. Ecology 81(5):1371-1382. https://doi.org/10.1890/0012-9658(2000)081[1371: SVIFAA]2.0.CO;2

Snodgrass JW, Meffe GK (1998) Influence of beavers on stream fish assemblages: effects of pond age and watershed position. Ecology 79(3):928-942. https://doi.org/10.1890/0012-9658(1998)079[0928: IOBOSF]2.0.CO;2

Suhonen S, Nummi P, Pöysä P (2011) Long term stability of boreal lake habitats and use by breeding ducks. Boreal Environ Res 16 (suppl. B): 71-80

Swanson GA, Meyer MI, Adomatis VA (1985) Foods consumed by breeding mallards on wetlands of southcentral North Dakota. J Wildl Manag 49:197-203

Thompson PL, Gonzalez A (2016) Ecosystem multifunctionality in metacommunities. Ecology 97(10):2867-2879. https://doi.org/10.1002/ecy.1502

Turner MG, Romme WH, Gardner RH, Hargrove WW (1997) Effects of patch size and fire pattern on early post-fire succession on the Yellowstone Plateau. Ecol Monogr 67(4):411-433

Turner MG, Gardner RH, Oneill RV, Oneill RV (2001) Landscape ecology in theory and practice. Springer, New York

van der Maarel E (1993) Some remarks on disturbance and its relations to diversity and stability. J Veg Sci 4(6):733-736. https://doi.org/10.2307/3235608

Vehkaoja M, Nummi P, Rask M, Tulonen T, Arvola L (2015) Spatiotemporal dynamics of boreal landscapes with ecosystem engineers: beavers influence the biogeochemistry of small lakes. Biogeochemistry 124(1-3):405-415. https://doi.org/10.1007/s10533-015-0105-4

Verberk WCEP, van Duinen GJA, Peeters TM, Esselink H (2001) Importance of variation in water-types for water beetle fauna (Coleoptera) in Korenburgerveen, a bog remnant in the Netherlands. Proc Sect Exp Appl Entomol 12:121-128

Washko S, Roper B, Atwood TB (2020) Beavers alter stream macroinvertebrate communities in north-eastern Utah. Freshw Biol 65(3):579-591. https://doi.org/10.1111/fwb.13455

White PS (1979) Pattern, process, and natural disturbance in vegetation. Bot Rev 45(3):229-299. https://doi. org/10.1007/BF02860857

Whitfield CJ, Baulch HM, Chun KP, Westbrook CJ (2015) Beaver-mediated methane emission: the effects of population growth in Eurasia and the Americas. Ambio 44(1):7-15. https://doi.org/10.1007/ s13280-014-0575-y

Willby NJ, Law A, Levanoni O, Foster G, Ecke F (2018) Rewilding wetlands: beaver as agents of within-habitat heterogeneity and the responses of contrasting biota. Philos Trans R Soc B 373(1761):20170444. https://doi.org/10.1098/rstb.2017.0444 
Wissinger SA, Gallagher LJ (1999) Beaver pond wetlands in northwestern Pennsylvania. Modes of colonization and succession after drought. In: Batzer D, Rader R, Wissinger S (eds) Invertebrates in freshwater wetlands of North America: ecology and management. Wiley, New York, pp 333-362

Wright JP, Jones CG, Flecker AS (2002) An ecosystem engineer, the beaver, increases species richness at the landscape scale. Oecologia 132(1):96-101. https://doi.org/10.1007/s00442-002-0929-1

Yee DA, Kehl S (2015) Order Coleoptera. Thorp and Covich's freshwater invertebrates. Academic Press, Cambridge, pp 1003-1042

Publisher's Note Springer Nature remains neutral with regard to jurisdictional claims in published maps and institutional affiliations. 